\title{
Environmental pathways and human exposure to manganese in southern Brazil
}

\author{
NADIR HERMES ${ }^{1}$, ROSANA C.S. SCHNEIDER ${ }^{2}$, DANIELA D. MOLIN ${ }^{2}$, GUILHERME Z. RIEGEL ${ }^{2}$, \\ ADILSON B. COSTA $^{3}$, VALERIANO A. CORBELLINI ${ }^{2}$, JOÃO P.M. TORRES ${ }^{1}$ and OLAF MALM ${ }^{1}$ \\ ${ }^{1}$ Laboratório de Radioisótopos Eduardo Penna Franca, Instituto de Biofísica Carlos Chagas Filho, \\ Universidade Federal do Rio de Janeiro, Av. Brig. Trompowsky, s/n, CCS, Bloco G, sub-solo, sala SS-061, \\ Ilha do Fundão, 21041-210 Rio de Janeiro, RJ, Brasil \\ ${ }^{2}$ Departamento de Química e Física, Universidade de Santa Cruz do Sul, \\ Avenida Independência, 2293, Bloco 12, Bairro Universitário, 96815-900 Santa Cruz do Sul, RS, Brasil \\ ${ }^{3}$ Departamento de Biologia e Farmácia, Universidade de Santa Cruz do Sul, \\ Avenida Independência, 2293, Bloco 12, Bairro Universitário, 96815-900 Santa Cruz do Sul, RS, Brasil
}

Manuscript received on March 5, 2012, accepted for publication on April 3, 2013

\begin{abstract}
The study of environmental pathways and human exposure to Manganese (Mn) in Southern Brazil was performed using two steps. The first step consisted of taking water samples from the surface of the Pardinho River. The average results from this technique showed a significant increase of pollutants, including increased levels of $\mathrm{Mn}$, above the environmentally acceptable standard recommended by the Brazilian National Environment Council. Additionally, 64 soil samples were taken from areas with and without agricultural activity. Many results were above the mean crust and did not indicate significant differences of Mn levels between the sampled areas. For the second step, 12 families were selected and assessed for exposure to $\mathrm{Mn}$ in a region with high levels of $\mathrm{Mn}$ in the soil. Most of the analyzed foods contained amounts of $\mathrm{Mn}$ above the reference values, indicating that food can be an important source of exposure. The Mn content from the hair of most subjects studied was also high compared to reference values from non-exposed populations. Although the contamination appeared to come from a natural origin, the results found in the present study showed that the Mn levels present in the Pardinho River Basin are a relevant public health issue.
\end{abstract}

Key words: manganese, human exposure, environmental levels, Mn.

\section{INTRODUCTION}

Manganese $(\mathrm{Mn})$ is one of the most abundant elements in the earth's crust, and average Mn concentrations in soils range between 500 and $900 \mathrm{mg} \cdot \mathrm{kg}^{-1}$ (World Health Organization - WHO 1981). Mn is an essential element found in all living organisms and can also be found in the air and in most water

Correspondence to: Rosana de Cassia de Souza Schneider E-mail: rosana@unisc.br supplies, though the principal mode of acquiring $\mathrm{Mn}$ is through food intake. In addition, $\mathrm{Mn}$ is a cofactor for a number of enzymatic reactions involved in phosphorylation, cholesterol and fatty acid synthesis (ATSDR 2000). Mn also plays an essential role in the immune system, in the regulation of cellular energy, in bone and connective tissue growth and in blood clotting. In the brain, $\mathrm{Mn}$ is an important cofactor for a variety of enzymes, including the 
antioxidant enzyme superoxide dismutase, and for enzymes involved in neurotransmitter synthesis and metabolism (Aschner et al. 2007).

Despite its vital nature, $\mathrm{Mn}$ has been known as a neurotoxin for at least 150 years (ATSDR 2000). Mn neurotoxicity was first identified as the cause of extrapyramidal syndrome in miners that were exposed to high concentrations of $\mathrm{Mn}$ while working in $\mathrm{Mn}$ mines. Chronic exposure to this metal can cause a neurodegenerative disease called "manganism", with symptoms that resemble Parkinson's disease (Barbeau 1984, Boudissa et al. 2006). The signs and symptoms of relatively high levels of exposure include postural instability, mood disorders and other psychiatric changes (i.e., depression, agitation, hallucinations) as well as parkinsonian symptoms, such as bradykinesia, rigidity, tremors, gait disturbance, postural instability and dystonia and/or ataxia. Cognitive deficits, such as memory impairment, reduced learning capacity, decreased mental flexibility, cognitive slowing and difficulty with processing visuo-motor and visuo-spatial information, have also been reported (Aschner et al. 2007).

It is not clear whether eating or drinking foods and liquids with excessive levels of manganese can cause symptoms of manganism (ATSDR 2000). Several reports have studied adverse effects after oral manganese exposure. These studies, which included children in their sample populations, have numerous limitations that preclude firm conclusions about the potential adverse effects from exposure to excess manganese. However, collectively, these studies have suggested that inhalation, ingestion of water and/or foodstuffs containing increased concentrations of manganese may result in adverse neurological effects (Kawamura et al. 1941, Kilburn 1987, Kondakis et al. 1989, Goldsmith et al. 1990, He et al. 1994, Iwami et al. 1994, Zangh et al. 1995, Alves et al. 1997, Batterman et al. 2011).

In the Pardinho River Basin area (RS, Brazil), previous studies have found excess $\mathrm{Mn}$ in soil (values ranging from 160 to $8,700 \mathrm{mg} \cdot \mathrm{kg}^{-1}$ ), food (values ranging 1.1 to $59.7 \mathrm{mg} . \mathrm{kg}^{-1}$ ) and human blood samples $(5.3 \%$ presented values over 50 $\left.\mu \mathrm{g} . \mathrm{L}^{-1}\right)$, indicating the possibility of environmental contamination that could be natural or due to agricultural practices (tobacco farming is the main agricultural activity in the area). In that region, there is a high manifestation of anxiety and depression cases associated with high serum levels of Mn (up to $800 \mathrm{ng} \cdot \mathrm{mL}^{-1}$ ), which confirmed the necessity of investigating the causes of high Mn levels in the rural area, including pesticide use. We highlight levels indicating $25 \mathrm{ng} . \mathrm{mL}^{-1}$ or more are enough to be detected alterations in central nervous system due to contamination with manganes. (Hermes and Torres 2003).

This contamination hypothesis is due to the local agricultural practices associated with tobacco farming where high doses of pesticides are applied during the tobacco seedling cultivation. In the tobacco production, mancozeb, a dithiocarbamate pesticide containing manganese, has been used to treat blue mold and antracnose for many years. A typical usage of mancozeb is $135 \mathrm{~g}$ for $45 \mathrm{~m}^{2}$, and it is applied 5 to 6 times per crop. Each molecule of this pesticide contains one manganese atom, which becomes incorporated into the soil due to the low mobility in that media.

Another standard, although not recommended, activity was that farmers would cultivate vegetables in areas that had previously been used to cultivate tobacco seedlings (Etges and Ferreira 2006). Accordingly, the authors of this paper asserted the necessity of investigating this situation. In that context, the present study is focused on assessing the environmental pathways and human exposure to $\mathrm{Mn}$ in the Pardinho River Basin.

\section{MATERIALS AND METHODS}

STUDY AREA

The Pardinho River Basin is located in the central region of the Rio Grande do Sul State, in southern Brazil, and it has an area of $1,075 \mathrm{~km}^{2}$ (Figure 1). 
The Pardinho River is approximately $50 \mathrm{~km}$ long and is a tributary of the Pardo River. The Pardinho and Pardo rivers belong to the Jacuí River watershed, the largest freshwater basin of the Rio Grande do Sul State. The agricultural development in this region is based on small to medium sized properties and resembles the $18^{\text {th }}$ century land tenure system in central Europe. Tobacco farming is the primary agricultural activity. The development of this region started with the arrival of German immigrants in the $19^{\text {th }}$ century and became established with the introduction of tobacco companies at the beginning of the 1900s (Etges 1991).

The study of environmental pathways and human exposure to $\mathrm{Mn}$ in the tobacco farming area of Southern Brazil was performed using two steps. The research design consisted of a quantitative observational analytical transversal study.

The first step consisted of taking surface water samples from the Pardinho River to assess the physical-chemical characteristics and Mn levels of the water. Additionally, soil samples were taken from areas with and without agricultural activity. For the second step, a specific investigation was performed to assess the Mn exposure of the inhabitants in places where the first step showed high environmental levels of Mn. In the selected area, the criteria for choosing residents were the distance, and in some cases isolation, from an urban center, and those with their own food production systems, including vegetables, grains and animals, inhabiting drainage area and having children. Drinking water, food and hair samples were taken for analysis from 12 families (47 individuals ranging in age from 0.5 to 76 years). This number represents $5 \%$ of the total inhabitants of those areas with the highest manganese levels in the soil. This can be considered a finite population of the selected participating families and is enough to reach a confidence interval of $95 \%(Z=1.96)$.

All the participants gave their permission to participate in the study (IRB approved informed consent) and were invited to answer a simple structured questionnaire designed to obtain information about age, food ingestion (home grown foods and foods acquired outside their properties) and the sources of the water they consumed. This project was registered in ethics committee number 1481/06.

\section{GROUND AND DRINKING WATER SAMPLES}

Surface water samples from the Pardinho River were taken at four sampling sites along the river (upstream, middle 1, middle 2 and downstream), from May 2004 to May 2005 (autumn, winter, spring and summer).

Physical-chemical variables, such as $\mathrm{pH}$, turbidity, chemical oxygen demand (COD), total phosphorus $(\mathrm{P})$, Kjeldahl nitrogen $(\mathrm{N})$, nitrate $\left(\mathrm{NO}_{3}{ }^{-}\right)$, suspended solids (SS) and dissolved oxygen (DO) as well as suspended, dissolved and total manganese (Mn), were analyzed following the APHA (1998). A water quality assessment was made according to resolution number 357 of CONAMA 2005 (National Environment Council) for the classification of Brazilian continental freshwater.

Water samples (volume equal to $1.5 \mathrm{~L}$ ) were collected using $0.5 \mathrm{~L}$ polypropylene bottles and preserved according to the analytical procedure as follows: without a preservation agent $(\mathrm{pH}$, turbidity, $\mathrm{NO}_{3}^{-}$, $\mathrm{SS}$, and dissolved and suspended $\mathrm{Mn}$ ), preserved with $\mathrm{H}_{2} \mathrm{SO}_{4}(\mathrm{P}, \mathrm{N}$, and COD), and preserved with $\mathrm{HNO}_{3}$ (total Mn). All samples were stored in coolers during transport to the laboratory.

In other selected areas, drinking water samples were collected to assess the exposure to Mn of the 12 families that live in the areas with the highest soil Mn content.

\section{SOIL SAMPLES}

In the first step, 64 sites were selected in the river basin, including areas with and without agricultural activity in the last few years (Figure 2). In areas with agricultural activity, soil was taken from tobacco fields (21 samples) and seedling production fields 


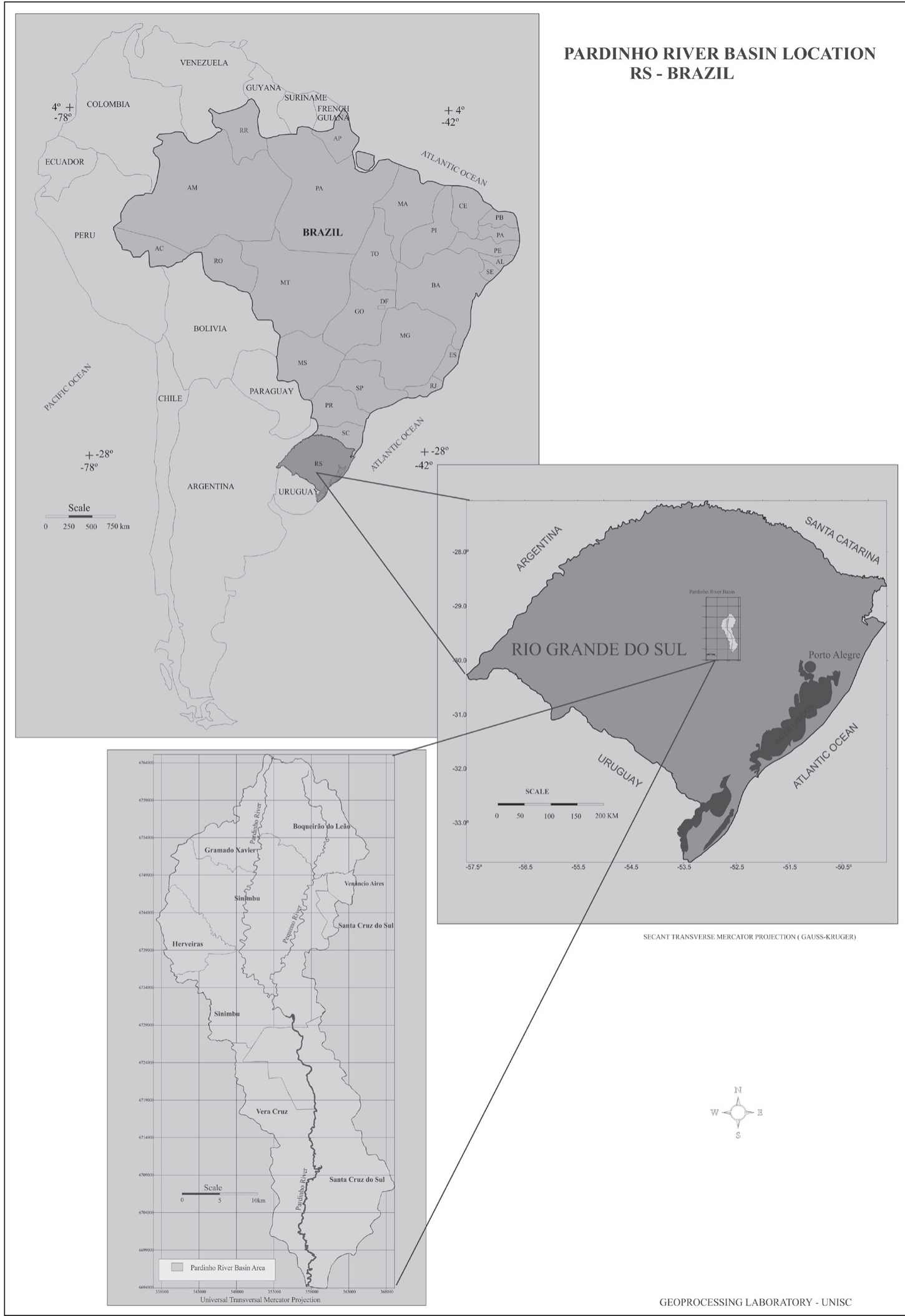

Figure 1 - Location of the Pardinho River Basin, RS, Brazil. 
(18 samples). In the second step, soil samples were taken where selected families lived (i.e., from their vegetable gardens and around the house). At each site, soil from at least 5 locations were randomly sampled from the upper horizon $(0-20 \mathrm{~cm})$ and combined to form a composite sample. A plastic bucket was used to mix subsamples, and a portion of approximately $0.5 \mathrm{~kg}$ was stored in a plastic bag. The samples were dried in a forced air oven at $45^{\circ} \mathrm{C}$ for 48 hours. The soil samples were then sized through a $<2 \mathrm{~mm}$ mesh sieve and analyzed for their total Mn content after digestion in PTFE (polytetrafluoroethylene) bombs with strong acids $\left(\mathrm{HNO}_{3}\right.$ and $\left.\mathrm{HF}\right)$ at $120^{\circ} \mathrm{C}$ for 12 hours. After an extraction with $\mathrm{KCl}\left(1 \mathrm{~mol} . \mathrm{L}^{-1}\right)$ for 5 minutes in a horizontal shaker, the solution was left standing overnight; subsequently, the bioavaliable Mn was measured. The Mn content was measured by flame atomic absorption spectrometry, fuelled by acetylene-air, Mn hollow cathode lamp (wavelength $279.5 \mathrm{~nm}$, slit width $0.2 \mathrm{~nm}, 5 \mathrm{~mA}$ ) with a double beam and a deuterium lamp for background correction (FAAS, Varian 55).

FOOD SAMPLES

Available food crop samples, including cabbage (Brassica oleracea-Acephala and Capitata group), lettuce (Lactuca sativa), beetroot (Beta vulgaris), carrot (Daucus carota), radish (Raphanus sativus) and beans (Phaseolus vulgaris), were also collected from the sites where the selected families lived. At harvest, the plants were divided into shoots and roots and thoroughly washed with de-ionized water to remove all visible soil particles. After milling, samples were digested in PTFE bombs with strong acids $\left(\mathrm{HNO}_{3}\right.$ and $\left.\mathrm{HF}\right)$ at $120^{\circ} \mathrm{C}$ for 12 hours. Manganese was measured using a graphite furnace atomic absorption spectrophotometer, applying $700^{\circ} \mathrm{C}$ and $2,400^{\circ} \mathrm{C}$ as the pyrolysis and atomization temperatures respectively, with a double beam and a deuterium lamp for background correction (GFAAS, Varian 55). Palladium was used as the chemical modifier.

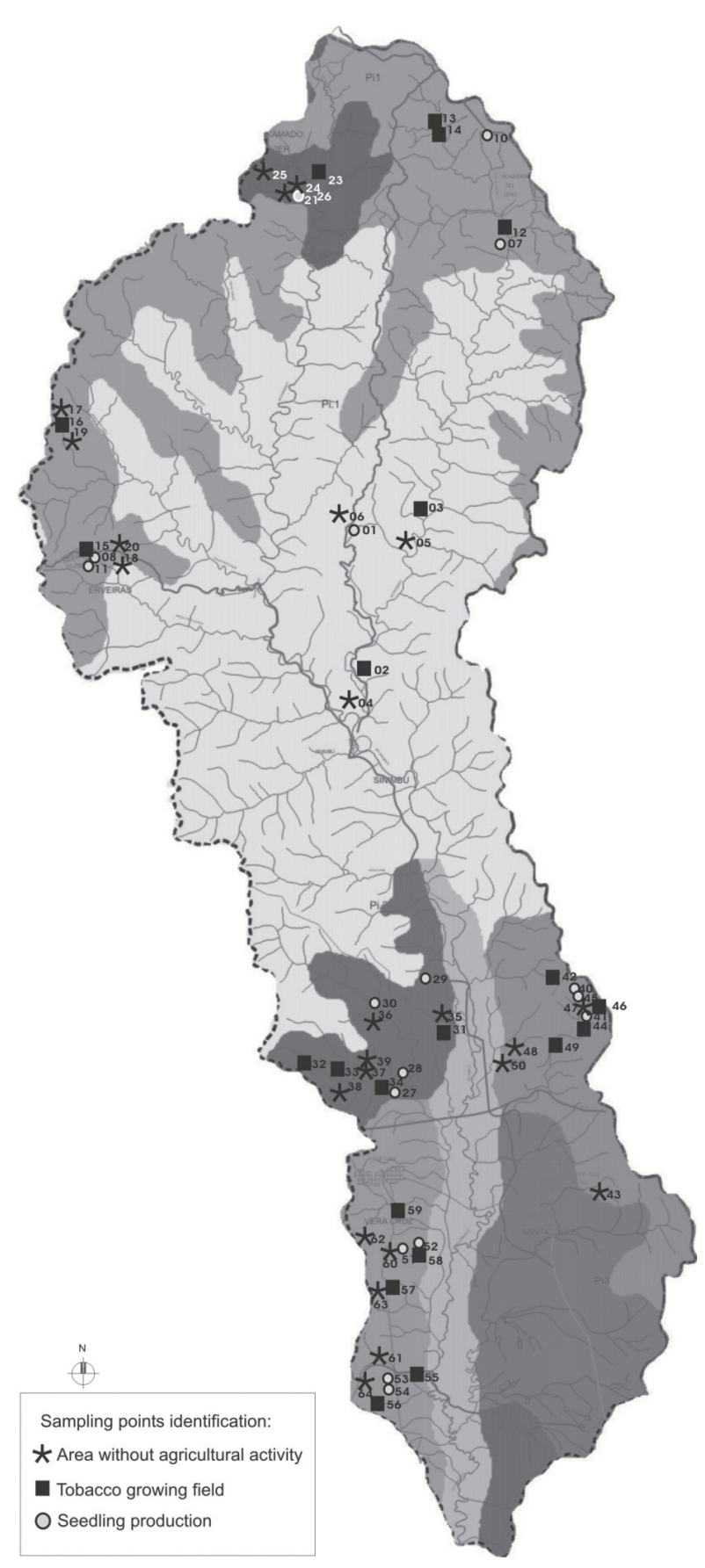

Figure 2 - Soil sampling points.

HAIR SAMPLES

Samples were collected using a pair of stainless-steel barber scissors. A small amount of hair was cut from the occipital region of the head and stored in a labeled paper envelope. The paper envelope containing the sample was then placed in a zip-lock polyethylene 
bag. Approximately $300 \mathrm{mg}$ of each hair sample was washed with $20 \mathrm{~mL}$ of acetone p.a. for $10 \mathrm{~min}$. After three short rinses with water to remove the organic solvent, the sample was washed three times for 10 min, each with $20 \mathrm{~mL}$ of a $1 \%$ solution of EXTRAN (MA-02, neutral, Merck). The concentration of the detergent and the number of repeated washings were chosen to provide the maximum removal of external contamination with a minimum loss of the endogenous elements (Miekeley et al. 1998); all washings were performed in an ultrasonic bath. After several final short rinses with Milli-Q water to remove the detergent, the samples were oven-dried at approximately $60^{\circ} \mathrm{C}$ overnight. The hair samples were digested in closed PTFE bombs and mineralized with concentrated nitric acid. The reagent and digestion conditions were chosen to achieve a complete mineralization and decomposition of the solid phase. After the acid digestion step, manganese levels were determined by means of a graphite furnace atomic absorption spectrophotometer, with a double beam and a deuterium lamp for background correction (GFAAS, Varian 55).

\section{STATISTICAL ANALYSIS}

All of the statistical analyses were performed using Graph Pad InStat ${ }^{\circledR} 3.00$ software (ANOVA, T-test, Pearson correlation) and Pirouette ${ }^{\circledR} 2.7$ software from Infometrix (Partial least squares regression - PLS). All tests were considered statistically significant at $P<0.05$.

\section{RESULTS AND DISCUSSION}

\section{GROUND WATER SAMPLES}

Table I shows the physical-chemical characteristics at 4 sampling points in the Pardinho River (upstream, middle 1, middle 2 and downstream) from 4 seasonal sampling dates.

The enrichment of contaminants along the river was primarily seen downstream at the point

TABLE I

Average of physical-chemical characteristics along the Pardinho river.

\begin{tabular}{|c|c|c|c|c|c|c|c|c|}
\hline Sampling point & $\begin{array}{c}\text { Turbidity } \\
\text { (uT) }\end{array}$ & pH & $\mathbf{N}$ & $\mathbf{P}$ & \multicolumn{4}{|c|}{$\left(\mathrm{mg} . \mathrm{L}^{-1}\right)$} \\
\hline Upstream & 1.9 & 5.2 & 0.41 & 0.037 & 0.23 & 4.2 & 3.6 & 3.8 \\
\hline STD & 2.7 & 0.2 & 0.35 & 0.048 & 0.05 & 3.8 & 2.8 & \\
\hline Middle 1 & 3.1 & 7.4 & 0.31 & 0.034 & 0.89 & 4.1 & 6.9 & 7.8 \\
\hline STD & 1.5 & 0.2 & 0.22 & 0.012 & 0.70 & 2.5 & 2.8 & \\
\hline Middle 2 & 6.4 & 7.4 & 0.63 & 0.035 & 0.96 & 3.3 & 7.2 & 8.6 \\
\hline STD & 0.7 & 0.3 & 0.72 & 0.008 & 0.78 & 2.4 & 2.3 & \\
\hline Downstream & 22.5 & 7.2 & 1.28 & 0.187 & 1.05 & 7.3 & 23.4 & 10.4 \\
\hline STD & 11.8 & 0.1 & 1.19 & 0.122 & 0.58 & 4.4 & 7.9 & \\
\hline$P($ Anova - linear tendency) & 0.0006 & $<0.0001$ & 0.0987 & 0.0115 & 0.1000 & 0.2860 & 0.0001 & - \\
\hline$P$ (Anova - among sampling points) & 0.0015 & 0.0001 & 0.2673 & 0.0140 & 0.3444 & 0.3541 & $<0.0001$ & - \\
\hline
\end{tabular}

where the river receives wastewater discharges from Santa Cruz do Sul, the biggest city in the study region. The increase in contaminants is particularly noticeable with regard to turbidity, total nitrogen, phosphorus and suspended solids levels. At the middle points (2 and 3), no significant differences were observed, showing similar contributions of pollutants. Due to pollutant loads from Santa Cruz do Sul, the downstream sampling point showed an increase in levels compared to other sampling points $(P<0.05)$, with the exception of nitrogen, nitrates, and COD. The phosphorous levels (mean 
ranging from 0.41 to $1.28 \mathrm{mg} . \mathrm{L}^{-1}$ ) were above the environmental acceptable standard recommended by the Brazilian National Environment Council, which set a concentration of $0.1 \mathrm{mg} . \mathrm{L}^{-1}$ as the limit for this class of water (Resolution CONAMA n ${ }^{\circ} 357$ ). Other parameters did not exceed the limits recommended by the CONAMA.

Applying the analysis of variance (ANOVA) to test the significant differences of the linear tendency along the sampling points (upstream to downstream), significant differences were observed in turbidity $(P=0.0006), \mathrm{pH}(P<0.0001)$, phosphorous $(P=0.0155)$ and suspended solids $(P=0.0001)$. The dissolved oxygen levels did not indicate anoxic conditions at the sampling points of the Pardinho River.

Figure 3 shows the average values of dissolved, suspended and total Mn at the sampling points and their standard deviation. High variability in the downstream results was observed with significant increments of total Mn along the river $(P=0.0042)$.
The mean results of total $\mathrm{Mn}\left(113.3 \mu \mathrm{g} . \mathrm{L}^{-1}\right)$ in the downstream samples exceeded the limit set by resolution $n^{\circ} 357$ of CONAMA (National Environment Council) for the classification of Brazilian continental freshwater $\left(100 \mu \mathrm{g} . \mathrm{L}^{-1}\right)$, which is supplied for public consumption after simplified treatment. The European Communities (EC 1989) set that value in $50 \mu \mathrm{g} . \mathrm{L}^{-1}$, but values up to $1,000 \mu \mathrm{g} . \mathrm{L}^{-1}$ in surface waters are accepted. Therefore, intensive systems of physical and chemical treatment may be necessary to adjust the quality of the public water supply (Homoncik et al. 2010, Marsden and Mackay 2001).

The dissolved Mn and suspended particle Mn levels showed a relative change along the river. Upstream, where the suspended solids content was low, most of the Mn was dissolved (63.9\%). Downstream, most of the Mn was suspended (64\%); a similar behavior was found in the Amazon River (83\%), the Mississippi River (98\%) and the Paraíba do Sul-Guandu River system (55\%) (Malm et al. 1988).

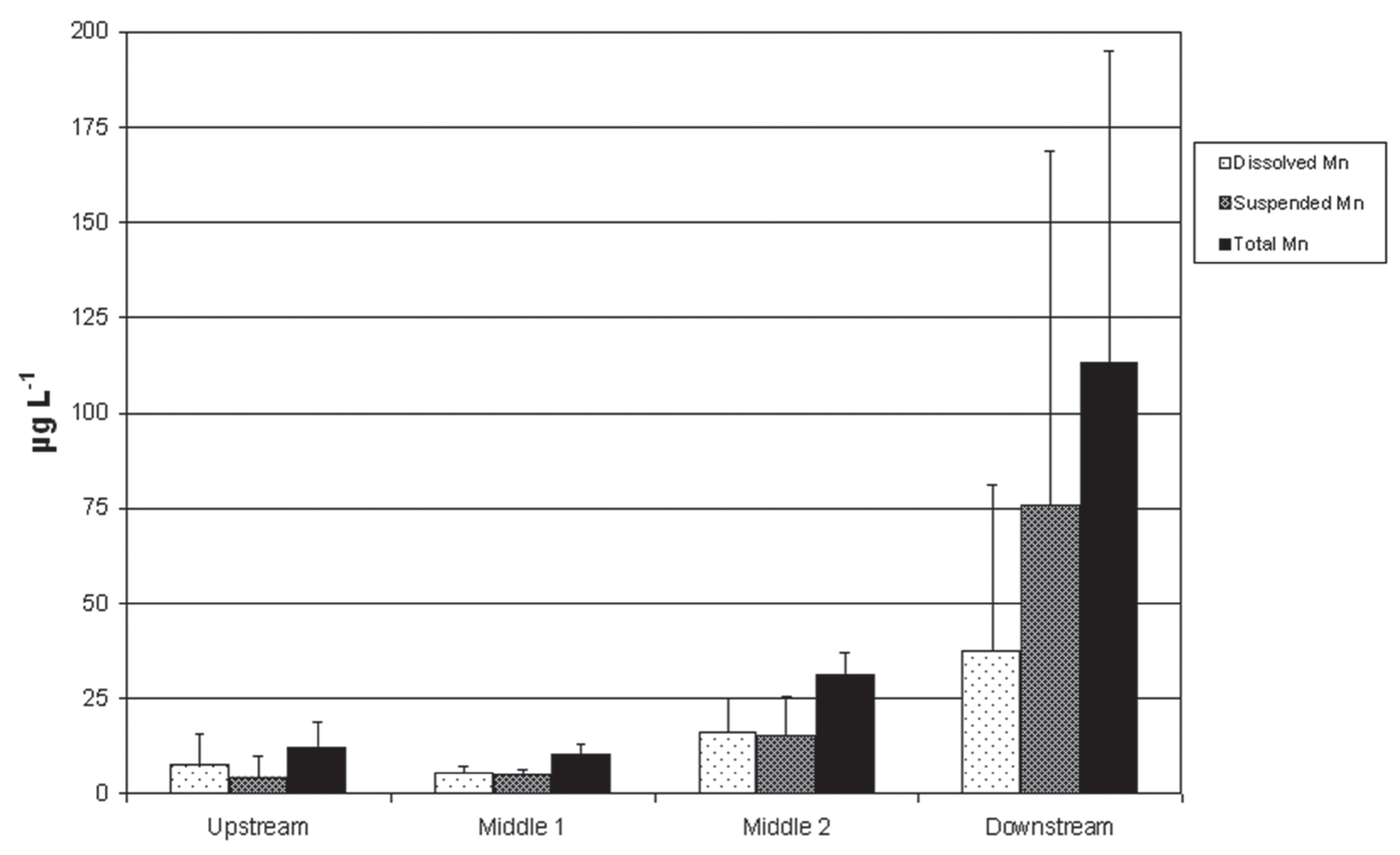

Figure 3 - Average and standard deviation of dissolved, suspended and total Mn in the Pardinho River. 
The relationship of the dissolved and suspended $\mathrm{Mn}$ as well as the variations in this behavior was investigated through multivariate analysis, which considered the physical-chemical characteristics. A partial least squares regression (PLS) showed that there was no correlation between these values $(r=0.24, \mathrm{P}>0.05)$. Several combinations of independent variables were tested, and no correlations were found.

SoIL

Table II summarizes the total Mn content from soils sampled in areas without agricultural practices, in the tobacco field and in seedling production areas.

TABLE II

Total Mn results of soil samples according to origin (without agricultural practices, Tobacco field and seedling production).

\begin{tabular}{|c|c|c|c|}
\hline & $\begin{array}{c}\text { Without } \\
\text { agricultural } \\
\text { practices } \\
\left(\mathrm{mg} \cdot \mathrm{kg}^{-1}\right) \\
(\mathrm{n}=25)\end{array}$ & $\begin{array}{l}\text { Tobacco } \\
\text { field } \\
\\
\left(\mathrm{mg} \cdot \mathrm{kg}^{-1}\right) \\
(\mathrm{n}=21)\end{array}$ & 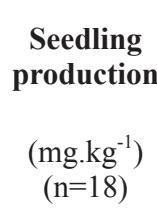 \\
\hline Range & $\begin{array}{l}175.9- \\
3,619.0\end{array}$ & $\begin{array}{l}117.6- \\
3,060.0\end{array}$ & $\begin{array}{l}202.6- \\
2,940.0\end{array}$ \\
\hline Average & $1,235.9$ & $1,136.9$ & 883.1 \\
\hline STD & 925.2 & 854.8 & 804.9 \\
\hline
\end{tabular}

A T-test was applied to the averages and showed that there were no significant differences among the sampling areas (areas without agricultural practices vs. the tobacco field: $P=0.710$; areas without agricultural practices vs. seedling production areas: $P=0.200$ ). Thus, there was no Mn enrichment in soils affected by agricultural activity used in tobacco growing fields, even using mancozeb (according to farmers information) which contains $\mathrm{Mn}$ in its formulation (approximately 20\%). High Mn levels appear to be due to natural factors (volcanic soil origin) according to what was previously described by Carvalho Filho et al. (2011), who stated that it was common to find birnessite $(\mathrm{MnO})$ in the soil of Rio Grande do Sul State. There are possibilities that Mn level can be due to fertilizers use, but there is not a historic that in this region were used compounds that had manganese sulfate, manganese oxide or manganese chelate in the formulation.

Several sites showed Mn levels above the mean crust value of $900 \mathrm{mg} \cdot \mathrm{kg}^{-1}$ (WHO 1981). Some of them, such as samples 3 and 5 (see Figure 2), were considered appropriate for the second part of this study. Families in that area are relatively isolated and distant from urban centers and produce their own food, including vegetables, grains and animals (i.e., little food was brought in). According to Bankovitch et al. (2003) and Rodríguez-Agudelo et al. (2006), the high Mn levels can be associated with particulate material inhalation, and therefore, the soil may be a contamination factor since manganese oxides in most of soils appears as finely dispersed particles (Carvalho Filho et al. 2011).

FAMILIES SELECTED FOR THE SECOND STEP

In the second step of the analysis to determine environmental exposure to $\mathrm{Mn}, 12$ families were selected for the determination of Mn levels in their drinking water, food, and hair. Table III shows their characteristics, including age, vegetable production, animals used as food sources and food acquired outside their properties (data taken from questionnaire). The families identified as F8a, F8b and F8c belonged to the same family group and lived in close proximity, cultivating the same foods and using the same source of water. The locations of all families in the watershed are shown in Figure 4 and are in an area where high levels of Mn were found in soils in the first part of this study. Most of these families live along a tributary of the Pardinho River that runs between the mountains and contains rough paths that are difficult to access. This location provided a pattern of isolation influenced by local environmental conditions that led to the production and consumption of their own foods in a somewhat controlled environment. 
TABLE III

Families' characteristics selected for the second step.

\begin{tabular}{|c|c|c|c|c|}
\hline Family & Integrants (age) & Vegetable garden & $\begin{array}{l}\text { Animals (as food } \\
\text { source) }\end{array}$ & $\begin{array}{l}\text { Foods acquired } \\
\text { outside }\end{array}$ \\
\hline $\mathrm{F} 1$ & father (74); son (46) & cucumber, potato and lettuce & pig, hen and cow & Not asked \\
\hline $\mathrm{F} 2$ & $\begin{array}{l}\text { grand father ( } 76) \text {; father }(43) \text {; } \\
\text { mother ( } 40) \text {; children }(18,6 \text { and } 2)\end{array}$ & $\begin{array}{l}\text { salads, parsley, turnip, } \\
\text { broccoli and cabbage }\end{array}$ & pig, hen and cow & $\begin{array}{l}\text { Cabbage, bean } \\
\text { and rice }\end{array}$ \\
\hline $\mathrm{F} 3$ & father (54); mother (59); son (17) & $\begin{array}{l}\text { salads, parsley, onion, } \\
\text { cauliflower and cabbage }\end{array}$ & pig and hen & rice \\
\hline F4 & father (33); mother (30) son (12) & $\begin{array}{c}\text { manioc, onion, potato, salads, } \\
\text { cucumber, cauliflower, carrot } \\
\text { and strawberrys }\end{array}$ & pig, hen and cow & rice \\
\hline F5 & $\begin{array}{l}\text { father (39); mother ( } 32) \text {; } \\
\text { children ( } 12 \text { and } 8)\end{array}$ & $\begin{array}{l}\text { cauliflower, beetroot, potato, } \\
\text { bean and strawberry }\end{array}$ & pig, hen and cow & rice and fruits \\
\hline F6 & $\begin{array}{l}\text { father }(37) \text {; mother }(30) \text {; } \\
\text { children }(12,10)\end{array}$ & salads, bean, potato and radish & pig, hen and cow & rice \\
\hline F7 & $\begin{array}{l}\text { father (33); mother (28); } \\
\text { daugther (2) }\end{array}$ & $\begin{array}{l}\text { salads, cabbage, onion, carrot, } \\
\text { cauliflower, radish and bean }\end{array}$ & pig, hen and cow & rice and potato \\
\hline F8a & $\begin{array}{l}\text { father (26); mother (16); } \\
\text { daugther (5 months) }\end{array}$ & & & \\
\hline $\mathrm{F} 8 \mathrm{~b}$ & father (45); mother (42) & $\begin{array}{l}\text { salads, broccoli, carrot } \\
\text { and cauliflower }\end{array}$ & pig, hen and cow & rice and bean \\
\hline $\mathrm{F} 8 \mathrm{c}$ & $\begin{array}{l}\text { father }(25) \text {; mother }(23) \text {; } \\
\text { children }(4 \text { e } 6)\end{array}$ & & & \\
\hline F9 & father (29); mother (25); son(3) & $\begin{array}{l}\text { salads, cabbage, onion, carrot } \\
\text { and cauliflower }\end{array}$ & pig, hen, lamb and cow & $\begin{array}{l}\text { rice, bean, tea } \\
\text { and sugar }\end{array}$ \\
\hline F10 & father (34); mother (26); son (2) & manioc, salads, potato and bean & pig, hen and cow & rice \\
\hline F11 & $\begin{array}{l}\text { father ( } 32) \text {; mother }(28) \text {; } \\
\text { children ( } 6 \text { and } 4)\end{array}$ & salads and bean & pig, hen and cow & rice \\
\hline F12 & father (32); mother (25); son (6) & bean, potato, salads & pig, hen and duck & rice \\
\hline
\end{tabular}

\section{Environmental results from selected family locations}

Drinking water and soil levels of Mn (total and the bioavailable fraction) were measured where the families lived. All families received drinking water from natural surface water sources, primarily coming from small creeks (springs). Three of the families had a well as their primary water source, and one family acquired water directly from the Pequeno River (tributary of Pardinho river), which was consumed after a single-step filtration (using a porous stone filter). Soil samples were taken where the vegetables were grown. Additionally, soil samples were taken from places near the homes where the children played, despite most houses having a lawn around them.

Table IV shows the results of the analyses of the drinking water and soil samples.

The drinking water results showed that there was no risk of exposure to Mn coming from this pathway. The Mn content was well below the acceptable limit established by WHO $\left(0.1 \mathrm{mg} \cdot \mathrm{L}^{-1}\right)$.

In soil samples, the total $\mathrm{Mn}$ contents were above the mean crust value, exceeding 2,000 mg. $\mathrm{kg}^{-1}$ in 6 of the family locations (F2, F8, F9, F10 and F11). More important than the total Mn results were the elevated levels of bioavailable Mn. 


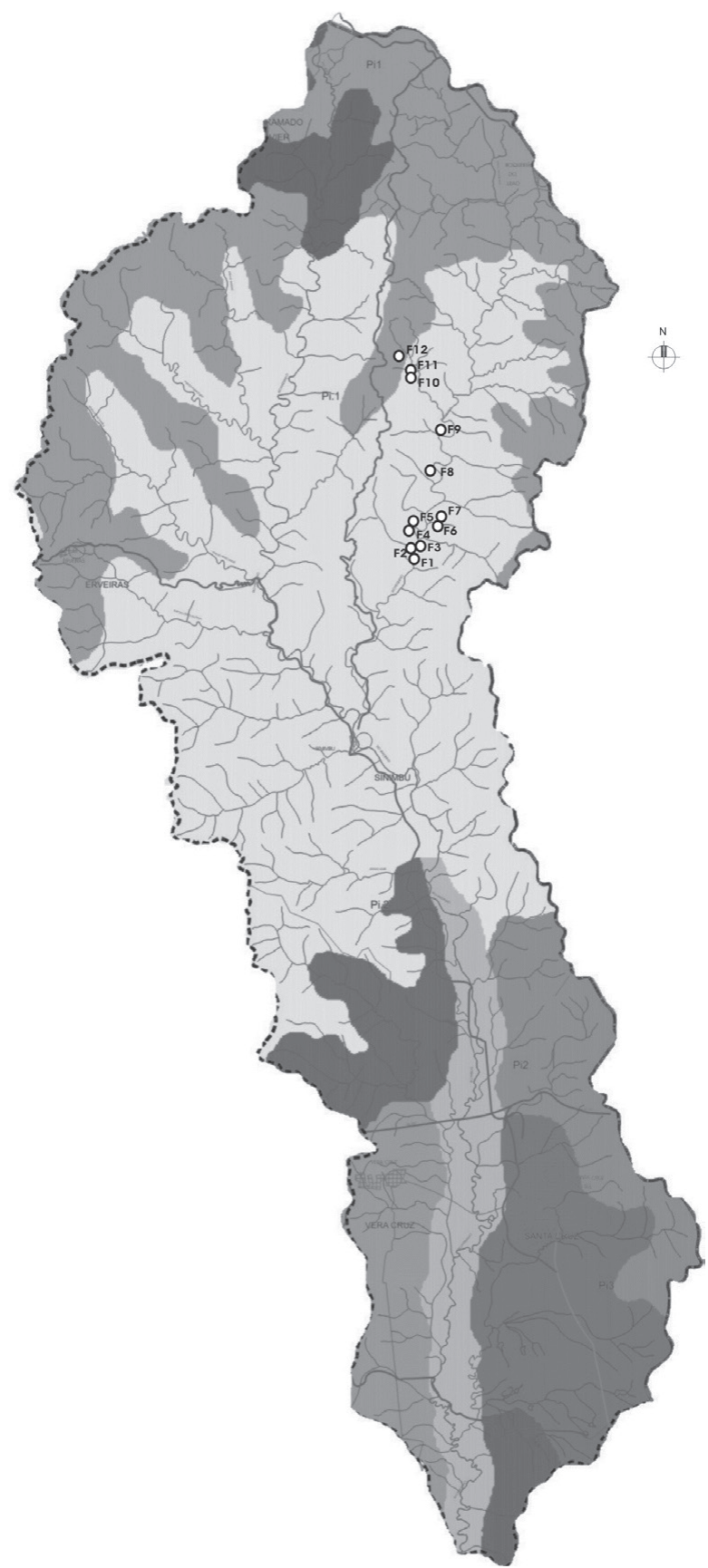

Figure 4 - Location of the selected family homes.

In agronomic terms, Mn levels above $5 \mathrm{mg} \cdot \mathrm{kg}^{-1}$ are considered elevated (Tedesco et al. 2004). Most family locations showed high bioavailable $\mathrm{Mn}$ content, reaching up to $71.5 \mathrm{mg} \cdot \mathrm{kg}^{-1}$.

To verify that the high content of the bioavailable $\mathrm{Mn}$ in the solids would influence the levels of $\mathrm{Mn}$ in the food and become an important path for Mn exposure, the available vegetable and egg samples were analyzed. Table V presents the values found for the vegetables and eggs sampled.

Most of the food analyzed presented results near and above reference values. Among them, the samples that stood out were as follows: cabbage Acephala group (all samples were above normal), cabbage - Capitata group (samples from F7, F8, F11 and F12 were above normal), lettuce (high content was found in samples from F2 and F8), beetroot (samples from F2 were 3 times higher than normal), carrots (all samples were above normal) and beans (both samples collected, from F6 and F10, were quite high, approximately 8 and 5 times higher than normal, respectively). Despite the high content of $\mathrm{Mn}$ in vegetables, no correlations were found with the Mn in soil. Only the Mn in carrots showed a significantly positive correlation with the total $\mathrm{Mn}$ in the soil, but not with the bioavailable Mn. Because few families produced beetroots, radishes and beans, no correlation could be made with these items. Though few, the results found in bean samples were well above the reference value (ranging from 48.2 to 81.8 mg. $\mathrm{kg}^{-1}, 4$ and 8 times the reference value $\left[10.6 \mathrm{mg} . \mathrm{kg}^{-1}\right]$, respectively) (USDA 2008). Families F6 and F10 cultivated beans in soils with high levels of bioavailable Mn. Due to its importance in the diet (staple diet in the South of Brazil), beans could be considered an important path of oral exposure to $\mathrm{Mn}$, and special attention should be given to this food. The results showed that further investigations need to be performed in which the number of samples (including rice, potatoes, flour, meat, among others) is increased and the daily intake of $\mathrm{Mn}$ from foods in the studied region is assessed.

\section{Hair samples from selected families}

The average, minimum and maximum concentrations of $\mathrm{Mn}$ in hair found in family integrants, as well as the standard deviation values are shown in Table VI. When the sampling was performed, 
TABLE IV

Mn content in drinking water and soil samples taken from selected families' places.

\begin{tabular}{|c|c|c|c|c|c|c|}
\hline Family & $\begin{array}{c}\text { Drinking } \\
\text { water source }\end{array}$ & $\begin{array}{l}\text { Drinking water } \\
\left.\text { Mn (mg. } \mathbf{L}^{-1}\right)\end{array}$ & $\begin{array}{c}\text { Total Mn } \\
\text { (vegetable garden } \\
\text { soil) }\left(\mathrm{mg} . \mathrm{kg}^{-1}\right)\end{array}$ & $\begin{array}{l}\text { Bioavailable Mn } \\
\text { (vegetable garden } \\
\text { soil) }\left(\mathrm{mg}^{\left.-\mathrm{kg}^{-1}\right)}\right.\end{array}$ & $\begin{array}{c}\text { Total } \mathrm{Mn} \text { in } \\
\text { soil around } \\
\text { house }\left(\mathrm{mg} \cdot \mathrm{kg}^{-1}\right)\end{array}$ & $\begin{array}{l}\text { Bioavailable Mn } \\
\text { in soil around } \\
\text { house }\left(\mathrm{mg} \cdot \mathrm{kg}^{-1}\right)\end{array}$ \\
\hline $\mathrm{F} 1$ & spring & 0.004 & $1,515.0$ & 35.0 & - & - \\
\hline $\mathrm{F} 2$ & well & 0.001 & $2,641.6$ & 47.3 & - & - \\
\hline F3 & well & $<0.001$ & - & - & - & - \\
\hline $\mathrm{F} 4$ & spring & 0.001 & $1,301.8$ & 30.9 & - & - \\
\hline F5 & spring & 0.001 & $1,491.0$ & 29.1 & - & - \\
\hline F6 & spring & 0.003 & $1,622.0$ & 71.5 & - & - \\
\hline F7 & spring & 0.002 & $1,858.8$ & 1.4 & 199.6 & 4.0 \\
\hline \multicolumn{7}{|l|}{ F8a } \\
\hline $\mathrm{F} 8 \mathrm{~b}$ & spring & 0.008 & $2,447.8$ & 0.9 & 861.2 & 52.4 \\
\hline \multicolumn{7}{|l|}{$\mathrm{F} 8 \mathrm{c}$} \\
\hline F9 & spring & 0.001 & $2,076.2$ & 0.3 & - & - \\
\hline F10 & well & 0.001 & $2,433.0$ & 36.9 & - & - \\
\hline F11 & spring & $<0.001$ & $1,320.6$ & 56.0 & - & - \\
\hline F12 & river & 0.003 & 775.3 & 23.0 & - & - \\
\hline
\end{tabular}

TABLE V

Mn content in foods collected in selected families' places.

\begin{tabular}{|c|c|c|c|c|c|c|c|c|c|c|c|c|c|c|c|}
\hline \multirow{2}{*}{ Food } & \multirow{2}{*}{$\begin{array}{l}\text { Reference } \\
\text { value* }\end{array}$} & \multicolumn{12}{|c|}{ Family } & \multicolumn{2}{|c|}{$\begin{array}{l}\text { Correlation coefficients } \\
\text { (r) with Mn soil content }\end{array}$} \\
\hline & & F1 & F2 & F3 & F4 & F5 & F6 & F7 & F8 & F9 & F10 & F11 & F12 & $\begin{array}{c}\text { Available } \\
\text { Mn }\end{array}$ & Total Mn \\
\hline Egg white & 0.11 & 0.21 & 0.14 & - & 0.47 & 0.18 & 0.15 & 0.14 & 0.15 & 0.15 & 0.15 & 0.15 & 0.14 & - & - \\
\hline Yolk & 0.55 & 0.46 & 0.52 & - & 0.41 & 0.49 & 0.25 & 0.36 & 0.61 & 0.36 & 0.65 & 0.40 & 0.40 & - & - \\
\hline $\begin{array}{l}\text { Cabbage } \\
\text { (Brassica oleracea- } \\
\text { Acephala Group) }\end{array}$ & 2.76 & 10.5 & 7.08 & - & 5.08 & 25.1 & 5.54 & - & 7.32 & 15.1 & 8.60 & 7.44 & - & $\begin{array}{c}-0.2626 \\
(\mathrm{P}=0.4335)\end{array}$ & $\begin{array}{c}-0.1598 \\
(\mathrm{P}=0.6909)\end{array}$ \\
\hline $\begin{array}{l}\text { Cabbage } \\
\text { (Brassica oleracea - } \\
\text { Capitata Group }\end{array}$ & 1.59 & 1.75 & 0.58 & - & 0.51 & - & 0.43 & 19.5 & 12.8 & - & - & 8.61 & 3.78 & $\begin{array}{c}-0.4907 \\
(\mathrm{P}=0.1499)\end{array}$ & $\begin{array}{c}0.0264 \\
(\mathrm{P}=0.9422)\end{array}$ \\
\hline $\begin{array}{l}\text { Lettuce } \\
\text { (Lactuca sativa) }\end{array}$ & 2.50 & - & 15.6 & - & - & - & 1.66 & 2.72 & 26.7 & 3.02 & 1.89 & 1.39 & 1.42 & $\begin{array}{c}-0.3023 \\
(\mathrm{P}=0.4667)\end{array}$ & $\begin{array}{c}0.5962 \\
(\mathrm{P}=0.1187)\end{array}$ \\
\hline $\begin{array}{l}\text { Beetroot } \\
\text { (Beta vulgaris) }\end{array}$ & 3.29 & - & 19.2 & - & 1.62 & - & - & - & - & - & - & - & - & & \\
\hline $\begin{array}{l}\text { Carrot } \\
\text { (Daucus carota) }\end{array}$ & 1.43 & - & 5.56 & - & 3.19 & 3.90 & 2.47 & 3.70 & 6.35 & 5.16 & - & - & - & $\begin{array}{c}-0.4123 \\
(\mathrm{P}=0.3580)\end{array}$ & $\begin{array}{c}0.8590 \\
(\mathrm{P}=0.0133)\end{array}$ \\
\hline $\begin{array}{l}\text { Radish } \\
\text { (Raphanus sativus) }\end{array}$ & 0.69 & - & - & - & 0.50 & - & - & 0.48 & 0.63 & - & - & - & - & - & - \\
\hline $\begin{array}{l}\text { Bean } \\
\text { (Phaseolus vulgaris) }\end{array}$ & 10.6 & - & - & - & - & - & 81.8 & - & - & - & 48.2 & - & - & - & - \\
\hline
\end{tabular}

* Reference value according to USDA National Nutrient Database for Standard Reference, Release 21 (2008). 
no integrant of family F3 was at home, and only one subject was at home in family F11. To compare results, Table VI also shows reference values and values taken from other studies.
Compared to the reference (maximum of 0.75 mg. $\mathrm{kg}^{-1}$, from the non-exposed population), high values were found in hair from most of the studied subjects (ranging from 0.17 to $39.59 \mathrm{mg} . \mathrm{kg}^{-1}$, mean

TABLE VI

Human hair levels of Mn in family integrants.

\begin{tabular}{|c|c|c|c|c|c|}
\hline Family & $\begin{array}{l}\text { Number of } \\
\text { integrants }\end{array}$ & $\begin{array}{l}\text { Age range } \\
\text { (years) }\end{array}$ & $\begin{array}{l}\text { Mn range } \\
\left(\mathrm{mg}^{\circ} \mathrm{kg}^{-1}\right)\end{array}$ & $\begin{array}{l}\text { Mean and standard } \\
\text { deviation }\left(\mathrm{mg} \mathrm{kg}^{-1}\right)\end{array}$ & Reference values* \\
\hline $\mathrm{F} 1$ & 2 & $46-74$ & $2.56-8.11$ & $5.34 \pm 3.92$ & Reference: $0.26-0.75$ \\
\hline $\mathrm{F} 2$ & 6 & $2-76$ & $0.21-29.75$ & $9.49 \pm 11.74$ & \\
\hline F4 & 3 & $12-35$ & $5.48-10.91$ & $7.33 \pm 3.10$ & Wroclaw: 0.601 \\
\hline F5 & 4 & $1-38$ & $0.83-7.06$ & $3.94 \pm 2.64$ & \\
\hline F6 & 5 & $10-59$ & $0.30-33.31$ & $7.24 \pm 14.58$ & South Poland: 2.41 \\
\hline F7 & 3 & $2-33$ & $0.24-0.72$ & $0.48 \pm 0.24$ & \\
\hline F8a & 3 & $0.5-26$ & $0.52-3.55$ & $2.15 \pm 1.53$ & Sweden: 0.560 \\
\hline $\mathrm{F} 8 \mathrm{~b}$ & 2 & $42-45$ & $1.21-39.59$ & $20.40 \pm 27.14$ & \\
\hline $\mathrm{F} 8 \mathrm{c}$ & 4 & $3-28$ & $1.10-1.52$ & $1.59 \pm 0.54$ & Rio de Janeiro: $0.1-1.8$ \\
\hline F9 & 3 & $4-30$ & $0.17-0.96$ & $0.84 \pm 0.62$ & \\
\hline F10 & 3 & $2-34$ & $0.55-1.26$ & $0.91 \pm 0.36$ & \\
\hline F11 & 1 & 32 & - & 11.22 & \\
\hline F12 & 2 & $6-25$ & $1.20-3.77$ & $2.49 \pm 1.82$ & \\
\hline Total & 41 & $1-76$ & $0.17-39.59$ & $5.32 \pm 9.03$ & \\
\hline
\end{tabular}

* Reference values for human hair (Miekeley et al. 1998), Mn concentrations (mg.kg-1) in hair for 83 subjects living in an urban area in south west Poland (Wroclaw city) (Chojnaca et al. 2006), for 266 subjects living in a non-industrialized region of south Poland (Silesian Beskid Slaski) (Nowak 1998), for 114 subjects from a urban population group living in north-east Sweden (Rodushkin and Axelssom 2000) and for 1091 subjects of Rio de Janeiro City (Miekeley et al. 1998).

$5.32 \pm 9.03 \mathrm{mg} \cdot \mathrm{kg}^{-1}$ ). Only one family (F7) did not present an average above the reference level. Approximately $75 \%$ of the results from all samples were above the maximum limit, reaching high values (10 to $40 \mathrm{mg} \cdot \mathrm{kg}^{-1}$ ) for 7 integrants (17\%) that belonged to families F2, F4, F6 and F8b.

The Mn content in the hair of the studied subjects was also compared to an urban area in southwest Poland (Wroclaw) and populations living in nonindustrialized areas of Poland (Silesian Beskid), Brazil (Rio de Janeiro) and Sweden (northeast). Average values obtained from families F1, F2, F4, F5, $\mathrm{F} 6$ and $\mathrm{F} 8 \mathrm{~b}$ (mean ranging from 3.94 to $20.4 \mathrm{mg} \cdot \mathrm{kg}^{-1}$ ) were above the values of the reference studies (mean ranging from 0.1 to $2.41 \mathrm{mg} \cdot \mathrm{kg}^{-1}$ ).
The results indicated a high intake of Mn by the selected family subjects. No significant correlations were found with age or soil levels $(P>0.05)$. However, most soil samples showed high contents (derived from Volcanic action), which could explain the high levels found in analyzed foods, the probable source of Mn. Because some studies have suggested that ingestion of foodstuffs containing increased concentrations of manganese may result in adverse neurological effects (Kawamura et al. 1941, Kilburn 1987, Kondakis et al. 1989, Goldsmith et al. 1990, He et al. 1994, Iwami et al. 1994, Zangh et al. 1995), the study area needs to be further investigated, with an assessment of the actual daily intake of Mn (increase sample numbers and analysis of other types of 
important daily foods, such as meat, flour, rice, among others) and testing of the prevalence of neurological effects of the people in these areas to assess if these exposure levels can adversely affect the health of the inhabitants of the Pardinho River Basin.

\section{CONCLUSION}

An environmental assessment was taken along the Pardinho River; a significant increase in Mn levels was found, which were above the environmentally acceptable standards recommended by the Brazilian National Environment Council (CONAMA). In addition, there was no direct relationship to anthropogenic activities because the results of the soil analysis did not indicate significant differences in Mn levels between samples from areas without agricultural activity vs. areas with seedling production or tobacco fields.

Drinking water results showed that there was no risk of exposure to Mn coming from this source. The soil samples from the families' properties showed levels above the crust mean value (ranging from 775.3 to $2,641.6 \mathrm{mg} \cdot \mathrm{kg}^{-1}$ ). Bioavailable Mn results were also high, reaching $71.5 \mathrm{mg} \cdot \mathrm{kg}^{-1}$, which was significantly above levels required for agronomical purposes. The soil has been recognized as the predominant factor of risk exposure, and this problem was reflected as a source of bioaccumulation in humans because Mn levels from hair samples of most of the subjects studied were high. Although the contamination seemed to have a natural origin, the results found in the present study showed that Mn levels in the Pardinho River Basin are a relevant public health issue that needs to be deeply investigated. The sampling design performed in this study showed that all of the studied family groups were exposed to excess Mn. To assess if these exposure levels can adversely affect the health of the living inhabitants of the Pardinho River Basin, a further study must be conducted to improve the sampling design, assess the actual daily intake of $\mathrm{Mn}$ and to test the prevalence of neurological effects associated with oral exposure.

\section{ACKNOWLEDGMENTS}

We would like to thank Patrick Rose, Michelle Butler and Marcelo Correa de Medeiros. Additionally, we thank PUIC/UNISC for the scholarships given to D.D.M. and the FAP/UNISC program for research support.

\section{RESUMO}

Neste estudo Da exposição humana e ambiental ao Manganês (Mn) no Sul do Brasil foi realizada em duas etapas. O primeiro passo consistiu na análise de amostras de águas da superfície do rio Pardinho. Os resultados médios desta tecnica mostraram aumento significativo de poluentes, incluindo aumento dos níveis de Mn acima do padrão aceitável para o ambiente recomendado pelo Conselho Nacional de Meio Ambiente. Além disso, 64 amostras de solo foram coletadas em áreas com e sem atividade agrícola. Muitos resultados ficaram acima da média e não indicaram diferenças significativas dos níveis de $\mathrm{Mn}$ entre as áreas amostradas. Para o segundo passo, 12 famílias foram selecionadas e avaliadas quanto à exposição ao Manganês nas regiões com níveis elevados de Mn no solo. A maioria dos alimentos analisados continham Mn acima dos valores de referência, indicando que o alimento pode ser uma fonte importante de exposição. O teor de Mn no cabelo da maioria dos indivíduos estudados foi também elevado em comparação com valores de referência de populações não-expostas. Apesar de a contaminação parecer vir de uma origem natural, os resultados encontrados neste estudo mostraram que os níveis de Mn presentes na Bacia do Rio Pardinho são um relevante problema de saúde pública.

Palavras-chave: manganês, exposição humana, níveis ambientais, Mn.

\section{REFERENCES}

Alves G, Thiebot J, Tracqui A, Delangre T, Guedon C And Lerebours E. 1997. Neurologic Disorders Due to Brain Manganese Deposition in a Jaundiced Patient Receiving Long-Term Parenteral Nutrition. JPEN J Parenter Enteral Nutr 21: 41-45. 
APHA. 1998. Standard methods for the examination of water and wastewater, $20^{\text {th }}$ ed., American Public Health Association. Washington, DC.

ASCHNER M, GuILARTE TR, SchneIDER JS AND ZHENG W. 2007. Manganese: Recent advances in understanding its transport and neurotoxicity. Toxicol Appl Pharmacol 221: 131-147.

ATSDR - AgENCY FOR TOXIC SUbSTANCES AND DiseASE REgisTRY. 2000. Toxicological Profile for Zinc. US Department of Health and Human Services. Public Health Service. http://www.atsdr.cdc.govytoxprofilesytp60.html.

BANKOVITCH V, CARRIER G, GAGNON C, NORMANDIN L, KenNedy G AND ZAYED J. 2003. Total suspended particulate manganese in ambient air in Montreal 19812000. Sci Total Environ 308: 185-193.

BARBEAU A. 1984. Manganese and extrapyramidal disorders (a critical review and tribute to Dr. George C. Cotzias). Neurotoxicol 5: 13-35.

BATTERMAN S, Su FC, JiA C, NAIDOO RN, THOMAS Robins T AND NAIK I. 2011. MAnganese and lead in children's blood and airborne particulate matter in Durban, South Africa. Sci Total Environ 409: 1058-1068.

Boudissa SM, Lambert J, Muller C, KenNedy G, Gareau L AND ZAYED J. 2006. Manganese concentrations in the soil and air in the vicinity of a closed manganese alloy production plant. Sci Total Environ 361: 67-72.

Carvalho Filho A, Curi N, Marques JJGSM, Shizato E, FreitAs DAF, JESUS EA AND MASSAHUd RTR. 2011 Manganese oxides an iron ore province soils, Minas Gerais, Brazil. R Bras Ci Solo 35: 793-804.

CHOJNACKA K, GóReCKA H AND GÓRECKI H. 2006. The influence of living habits and family relationships on element concentrations in human hair. Sci Total Environ 366: $612-620$

CONAMA. 2005. Environment National Council. Resolution do CONAMA, $N^{\circ}$ 357. Federal Official Gazette of Brazil, Brasília.

EC - EUROPEAN COMMUNITIES. 1989. Quality of surface water intended for the abstraction of drinking water. Regulations S.I. $n^{\circ} 294$.

ETGES VE. 1991. Sujeição e resistência: os camponeses gaúchos e a indústria do fumo. $1^{\text {a }}$ ed., Edunisc, Santa Cruz do Sul.

ETGES VE AND FERREIRA MAF. 2006. A produção de Tabaco: Impactos no ecossistema e na saúde humana na região de Santa Cruz do Sul/RS. $1^{\text {a }}$ ed., Edunisc, Santa Cruz do Sul.

GOLDSMITH JR, HERISHANU Y, ABARBANEL JM AND WEINBAUM Z. 1990. Clustering of Parkinson's disease points to environmental etiology. Arch Env Health 45: 88-94.

HE P, LIU DH AND ZHANG GO. 1994. Effects of high-level manganese sewage irrigation on children's neurobehavior. Chung Hua Yu Fang I Hsueh Tsa Chih 28: 216-218.

Hermes N AND TORRES JPM. 2003. Análise de manganês nos alimentos produzidos em canteiros de mudas de tabaco na bacia hidrográfica do rio Pardinho. Tecno-Lógica 7: 97-106.
HOMONCIK SC, MACDONALD AM, HEAL KY, DOCHARTAIGH BEO AND NGWENYA BT. 2010. Manganese concentrations in Scottish groundwater. Sci Total Environ 408: 2467-2473.

IWAMI O, WATANABE T, MOON CS, NAKATSUKA H AND IKEDA M. 1994. Motor neuron disease on the Kii Peninsula of Japan: excess manganese intake from food coupled with low magnesium in drinking water as a risk fator. Sci Total Environ 149: 121-135.

KAWAMURA R, IKUTA H, FUKUZIMI S, YAMADA R AND TSUBAKI S. 1941. Intoxication by manganese in well water. Exp Med 18: 145-169.

KILBURN CJ. 1987. Manganese. malformations and motor disorders: Findings in manganese-exposed population. Neurotoxicology 8: 421-429.

Kondakis XG, Makris N, LeOtsinidis M, PRINOU M AND PAPAPETROPOULOS T. 1989. Possible health effects of high manganese concentration in drinking water. Arch Environ Health 44: 175-178

Malm O, Pfeiffer WC, Fiszman M and Azcue JM. 1988 Transport and availability of heavy metals in the Paraiba do Sul - Guandu river system. Rio de Janeiro state. Brazil. Sci Total Environ 75: 201-209.

MARSDEN MW AND MACKAY DW. 2001. Water quality in Scotland: the view of the regulator. Sci Total Environ 265: 369-386.

MieKeley N, CARNeIRO MTWD AND SILVEIRA CLP. 1998. How reliable are human hair reference intervals for trace elements? Sci Total Environ 218: 9-17.

NowAK B. 1998. Contents and relationship of elements in human hair for a non-industrialized population in Poland. Sci Total Environ 209: 59-68.

RodRÍGUEZ-AgUdelo Y, RIOJAS-RODRÍGUEZ H, Ríos C Rosas I, Pedraza ES, Miranda J, Siebe C, Texcalac JL AND BURGOA CS. 2006. Motor alterations associated with exposure to manganese in the environment in Mexico. Sci Total Environ 368: 542-556.

RoDUSHKIN I AND AXELSSOM MD. 2000. Application of double focusing sector field ICP-MS for multielemental characterization of human hair and nails. Part II. A study of the inhabitants of northern Sweden. Sci Total Environ 262: $21-36$.

Tedesco J, Gianello C, Anghinoni I, Bissani CA, CAMARgo FAO AND WiETHOLTER S. 2004. Manual de adubação e de calagem para os estados do Rio Grande do Sul e de Santa Catarina. $10^{\mathrm{a}}$ ed., Porto Alegre, Sociedade Brasileira de Ciência do Solo - Núcleo Regional Sul.

USDA - U.S. DEPARTMENT OF AgRICULTURE, AgRICULTURAL RESEARCH SERVICE. 2008. USDA National Nutrient Database for Standard Reference, Release 21. Nutrient Data Laboratory Home Page, http://www.ars.usda.gov/ nutrientdata.

WHO. 1981. Environmental health criteria: manganese. World Health Organization, Geneva.

ZHANG G, LIU D AND HE P. 1995. Effects of manganese on learning abilities in school children. Chung Hua Yu Fang I Hsueh Tsa Chih 29: 156-158. 